\title{
Heterogeneous Clinical Manifestations of Cushing's Syndrome in a Family with Primary Pigmented Nodular Adrenocortical Disease
}

\section{Shih-Chen Tung ${ }^{1^{\star}}$, Daw-Yang Hwang ${ }^{2}$, Joseph W. Yang ${ }^{3}$, Hwee-Yeong Ng ${ }^{4}$ and Chien-Te Lee ${ }^{4}$}

${ }^{1}$ Division of Endocrinology and Metabolism, Department of Internal Medicine, Kaohsiung Chang Gung Memorial Hospital and Chang Gung University College of Medicine, Kaohsiung, Taiwan; 123 Ta-Pei Road, Niao-Sung District, Kaohsiung City 83301, Taiwan

${ }^{2}$ Division of Nephrology, Department of Internal Medicine, Kaohsiung Medical University Hospital and Kaohsiung Medical University, Kaohsiung, Taiwan; No.100, Tzyou 1st Road, Kaohsiung City 807, Taiwan

${ }^{3}$ Division of Urology, Department of Surgery, Kaohsiung Chang Gung Memorial Hospital and Chang Gung University College of Medicine, Kaohsiung, Taiwan; 123 TaPei Road, Niao-Sung District, Kaohsiung City 83301, Taiwan

${ }^{4}$ Division of Nephrology, Department of Internal Medicine, Kaohsiung Chang Gung Memorial Hospital and Chang Gung University College of Medicine, Kaohsiung, Taiwan; 123 Ta-Pei Road, Niao-Sung District, Kaohsiung City 83301, Taiwan

"Corresponding author: Shih-Chen Tung, Department of Internal Medicine, Kaohsiung Chang Gung Memorial Hospital and Chang Gung University College of Medicine, Kaohsiung, postal address: 123 Ta-Pei Road, Niao-Sung District, Kaohsiung City 83301, Taiwan, Tel: +886 975056088; Fax: +886 7 7323353; E-mail: tungqq44112@yahoo.com.tw

Rec date: Aug 15, 2014, Acc date: Oct 14, 2014, Pub date: Oct 24, 2014

Copyright: (c) 2014 Tung SC et al. This is an open-access article distributed under the terms of the Creative Commons Attribution License, which permits unrestricted use, distribution, and reproduction in any medium, provided the original author and source are credited.

\begin{abstract}
Purpose: To evaluate the clinical manifestations of Cushing's Syndrome (CS) and associated genetic mutation in patients with Primary Pigmented Nodular Adrenocortical Disease (PPNAD).

Methods: Seven family members were screened for mutations of the PRKAR1A gene. Gene mutation screening used genomic DNA (from peripheral blood leukocytes and, in some cases, adrenal gland tissue) and subsequent DNA sequencing. The five patients showing genetic mutation were assessed clinically for baseline cortisol and adrenocorticotropic hormone and adrenal imaging studies (abdominal computed tomography and adrenal scintigraphy). Low-dose and high-low dexamethasone suppression tests were performed in these five patients.

Results: PRKAR1A gene mutation was detected in five of the seven family members. Four of the five gene mutation-positive patients presented with overt CS due to pathology-proven PPNAD. After unilateral adrenalectomy in these four patients, overt CS persisted for two patients and CS symptoms abated for the other two. The remission period of CS was $>11$ years in one instance (case III-2) and continues for $>12$ years in the other (case II-4), with no observable disease of the contralateral non-resected adrenal gland. For each of the two remission patients, one adrenal gland had been larger (by abdominal computed tomography) and had had stronger function (by 131I-6 $\beta-$ iodomethyl-19-norcholesterol scintigraphy) than the other. In one (case III-2) of the two remission patients, one adrenal displayed focal PPNAD while the other displayed diffuse PPNAD. The clinical manifestations of CS did not resolve after unilateral adrenalectomy in case II-2 and III-7. The fifth gene mutation-positive patient (case III-4) is still in the latent stage of CS.
\end{abstract}

Conclusions: The clinical manifestations of CS and adrenal image features in patients with PPNAD are heterogeneous. Detailed adrenal imaging of these patients is necessary to assist with the decision to perform unilateral adrenalectomy.

Keywords Cushing's syndrome; Primary pigmented nodular adrenocortical disease

\section{Introduction}

Primary Pigmented Nodular Adrenocortical Disease (PPNAD) is a rare cause of adrenal Cushing's Syndrome (CS). It occurs sporadically or as part of a familial syndrome called Carney Complex (CNC) [1]. PPNAD was observed in about $26-32 \%$ of CNC patients [2,3]. However, histological evidence of PPNAD was found in almost every patient with CNC who underwent an autopsy [2]. In the disease process of PPNAD, both adrenal glands are involved and feature small brown black nodules separated by atrophic adrenal cortex. The adrenal sizes associated with PPNAD range from small to slightly enlarged. The cut surfaces of the adrenal nodules vary in color from yellow-tan to gray, brown, and black [4]. Microscopically, the nodules consist of large cortical cells with lipofuscin pigment and internodular cortical atrophy $[1,5]$.

We present the clinical manifestations of CS and the adrenal imaging and pathological features of family members with PPNAD and a common, single mutation of the PRKAR1A gene.

\section{Subjects and Methods}

\section{Subjects}

Seven members of a family were screened for mutation of the PRKAR1A gene. The five patients with the mutation were aged 24-45 years and included one female and four males. Four of the five patients 
presented with clinical features of CS and eventually had an adrenalectomy.

\section{Methods}

Plasma and urine cortisol levels were measured by commercial radioimmunoassay kits. Plasma Adrenocorticotropic Hormone (ACTH) levels were measured by immunoradiometric assay. Lowdose and high-dose dexamethasone suppression tests were performed in these five gene mutation patients. Adrenal imaging studies included abdominal Computed Tomography (CT) and adrenal scintigraphy.

Genomic DNA was extracted from peripheral blood leukocytes from each of the seven family members using the QIAamp DNA Blood Mini Kit (Qiagen GmbH, Hilden, Germany) and from paraffinembedded adrenal gland tissue available for four of the seven family members using the QuickExtract FFPE DNA Extraction Kit (Epicentre Biotechnologies, Madison, WI) according to the manufacturer's protocol.

All 10 exons of the PRKAR1A gene and their intron-exon boundaries were amplified by polymerase chain reaction (PCR) using primers described previously [6]. Semi-nested PCR analysis of exon 2 in the DNA obtained from the paraffin-embedded adrenal tissue was performed using the reverse primer 5'CAACCTCTCAAAGTATTCCCTGA-3' for the second PCR cycle. PCR products were separated by electrophoresis on a $1.5 \%$ agarose gel and sequenced by ABI 3730 XL DNA Analyzer (Applied Biosystems, Foster City, CA). The study protocol was approved by the institutional review board, and informed consent was obtained from each of the seven family members.

\section{Results}

\section{Family member studies Case II-2 (index patient)}

The detailed history of this index patient was reported by Tung et al., 2005 [7]. Briefly, a 41-year-old man (Figure 1), born in November 1949, came to our outpatient department in October 1990 with cushingoid appearance. The patient's father also had cushingoid features, but due to his death, his clinical characteristics were not analyzed as part of this study. Endocrine studies of this index patient revealed adrenal CS (Table 1). A paradoxical rise of 24-h urinary free cortisol (UFC) to 2-day high-dose dexamethasone suppression test (HDDST, $2 \mathrm{mg}$ dexamethasone every 6 hours orally for a total of 8 doses) was observed (Table 1). Adrenal scintigraphy with 131I-63iodomethyl-19-norcholesterol (NP-59) showed uptake in both adrenal glands on the seventh day after NP-59 injection. Abdominal Magnetic Resonance Imaging (MRI) in July 1991 showed a tiny nodule at the lateral limb of the right adrenal gland [7]. A right total adrenalectomy was performed on October 4, 1991, and diffuse PPNAD was confirmed pathologically [7]. Two weeks after right adrenalectomy, a repeated 2-day Low-Dose Dexamethasone Suppression Test (LDDST, $0.5 \mathrm{mg}$ dexamethasone every 6 hours orally for a total of 8 doses) and 2-day HDDST still could not suppress plasma cortisol or 24-h UFC levels. A repeated CT of the abdomen on October 22, 1991 revealed a left adrenal nodule, $2.0 \mathrm{~cm}$ in diameter, which was missed during the reading of a previous abdominal CT because of its unusual location in the left renal hilar region [7]. A left total adrenalectomy was performed in December 1991, and diffuse PPNAD was proved microscopically. Features of CS then resolved gradually.
A left thyroid nodule was palpated in February 2002. Ultrasonography of the thyroid demonstrated two hypoechoic nodules in the left lobe and three in the right lobe [7]. Bilateral total thyroidectomies and excision of left lateral neck lymph nodes were performed in March 2002. Papillary Thyroid Carcinomas (PTC) with metastases to multiple lymph nodes were confirmed pathologically [7]. Analysis of this patient's genomic DNA obtained from peripheral blood leukocytes and paraffin-embedded left adrenal tissue both showed a c.46C $>$ T nucleotide mutation (p.R16X nonsense amino acid mutation) in the PRKAR1A gene.

\section{Case III-1}

This woman aged 26 years and 7 months (the eldest daughter of the index patient; born in September 1974) (Figure 1) came to our outpatient department in April 2001 for screening of CS because her father had PPNAD. She was previously diagnosed with PTC based on pathology and underwent bilateral total thyroidectomy at another hospital in August 2000. Her height was $153 \mathrm{~cm}$; weight, $71 \mathrm{~kg}$; and blood pressure, 120/80 mm Hg. Cushingoid features were not present, except for abdominal obesity. Plasma cortisol level was suppressed to $0.56 \mu \mathrm{g} / \mathrm{dL}$ with overnight LDDST ( $1 \mathrm{mg}$ dexamethasone orally at 2300 h). Analysis of this patient's genomic DNA obtained from peripheral blood leukocytes did not show mutation of the PRKAR1A gene.

\section{Case III-2}

The detailed history of this patient was reported by Tung et al., 2012 [8]. Briefly, a 24-year-old woman (the second daughter of the index patient; born in November 1975) (Figure 1) was admitted in May 2000 due to cushingoid appearance for about 6 months and weight gain of $10 \mathrm{~kg}$ over the preceding 9 months. Endocrine studies revealed adrenal CS. Paradoxical increase of 24-h UFC to 2-day HDDST was found (Table 1). Abdominal CT revealed a left adrenal nodule $(3 \times 2 \mathrm{~cm}$ diameter) [8] and a normal-sized right adrenal gland. Adrenal scintigraphy using NP-59 showed tracer uptake in the left adrenal gland and non-visualization of the right adrenal gland throughout the examination course. A retroperitoneoscopic left total adrenalectomy was performed in July 2000. The cut surface of the left adrenal nodule was yellow-tan without obvious black pigmentation. Microscopically, non-pigmented adrenocortical adenoma was the major portion and focal PPNAD was the minor portion of this left adrenocortical nodule [8]. The cushingoid features of the patient gradually disappeared thereafter. A very low baseline morning plasma cortisol level $(0.97$ $\mu \mathrm{g} / \mathrm{dL}$ at $0800 \mathrm{~h}$ ) was measured 1.5 months after left adrenalectomy. Six months later, the baseline plasma cortisol and ACTH levels at 0800 h were normal $(8.7 \mu \mathrm{g} / \mathrm{dL}$ and $38.8 \mathrm{pg} / \mathrm{mL}$, respectively). Apparent cushingoid features still had not returned 122 months later, despite non-suppression of the plasma cortisol level $(7.12 \mu \mathrm{g} / \mathrm{dL})$ by overnight LDDST.

In May 2011, the patient was re-admitted because of a $13 \mathrm{~kg}$ weight gain during the preceding 6 months. A paradoxical rise of 24-h UFC during the 2-day HDDST was observed [8]. Both abdominal CT and MRI showed a normal-sized right adrenal gland. Subtotal right adrenalectomy (about $80 \%$ of the right adrenal gland resected) via the traditional thoracoabdominal approach was performed on May 25, 2011. The cut surface of the right adrenal gland was grossly observed to be brown-black. Diffuse PPNAD was confirmed microscopically [8]. Analysis of this patient's genomic DNA obtained from peripheral blood leukocytes and bilateral adrenal tissues both showed a c.46C $>\mathrm{T}$ mutation (p.R16X) in the PRKAR1A gene [8]. 
Citation: Tung SC, Hwang DY, Yang JW, Ng HY, Lee CT (2014) Heterogeneous Clinical Manifestations of Cushing's Syndrome in a Family with Primary Pigmented Nodular Adrenocortical Disease. J Steroids Horm Sci 5: 144. doi:10.4172/2157-7536.1000144

Page 3 of 6

\section{Case III-3}

This 23-year-old woman (the third daughter of the index patient; born in March 1978) (Figure 1) came to our outpatient department in December 2000 for screening of CS. Her height was $156 \mathrm{~cm}$; weight, 45 $\mathrm{kg}$; and blood pressure, 90/60 mm Hg. Cushingoid features were not found during physical examination. Plasma cortisol level was suppressed to $0.90 \mu \mathrm{g} / \mathrm{dL}$ by overnight LDDST. Analysis of genomic DNA obtained from peripheral blood leukocytes demonstrated no mutation of the PRKAR1A gene.

\section{Case III-4}

This man aged 21 years and 5 months (the fourth child of the index patient; born in November 1979) (Figure 1) came to our outpatient department in April 2001 for screening of CS because of his father's PPNAD. His height was $169 \mathrm{~cm}$; weight, $60 \mathrm{~kg}$; and blood pressure, $120 / 80 \mathrm{~mm} \mathrm{Hg}$. Cushingoid features were not observed during physical examination. Baseline plasma cortisol and ACTH levels at $0800 \mathrm{~h}$ were $5.32 \mu \mathrm{g} / \mathrm{dL}$ and $42.1 \mathrm{pg} / \mathrm{mL}$, respectively. Plasma cortisol was suppressed to $3.23 \mu \mathrm{g} / \mathrm{dL}$ and $4.57 \mu \mathrm{g} / \mathrm{dL}$ (Table 1) by overnight LDDST in April 2001 and December 2006, respectively. Image studies and adrenalectomy were not performed because of the absence of clinical manifestations of CS. However, analysis of this patient's genomic DNA obtained from peripheral blood leukocytes identified a c.46C $>$ T mutation (p.R16X) in the PRKAR1A gene.

\begin{tabular}{|c|c|c|c|c|c|}
\hline Tests & Case II-2 & Case II-4 & Case III-2 & Case III-7 & Case III-4 \\
\hline \multicolumn{6}{|l|}{ Baseline plasma cortisol level ( $\mu \mathrm{g} / \mathrm{dL})$} \\
\hline $0800 \mathrm{~h}$ (normal range, 9-23) & 37.9 & 26.1 & 17.5 & 17.3 & 5.32 \\
\hline 1600-2200 h (normal range, 3-13) & 33.8 & 20.4 & & 14.1 & \\
\hline $\begin{array}{l}\text { Baseline 24-h urinary free cortisol level } \\
(\mu g / 24-h) \text { (normal range, 34-122) }\end{array}$ & 1008 & 786 & 952 & & \\
\hline Baseline plasma ACTH level (pg/mL) & 5.10 & 8.29 & 2.05 & 14.6 & 42.1 \\
\hline \multicolumn{6}{|l|}{$0800 \mathrm{~h}$ (normal range, 9-52) } \\
\hline \multicolumn{6}{|c|}{ Overnight low-dose dexamethasone suppression test ${ }^{\star}$} \\
\hline Plasma cortisol level at $0800 \mathrm{~h}$ & 32.3 & 24.3 & 20.9 & 13.8 & 4.57 \\
\hline \multicolumn{6}{|c|}{ Two-day low-dose dexamethasone suppression test ${ }^{\star *}$} \\
\hline Plasma cortisol level at $0800 \mathrm{~h}$ & 36.9 & 20.1 & 17.3 & & \\
\hline 24-h urinary free cortisol level & 1162 & 762 & 1066 & & \\
\hline \multicolumn{6}{|c|}{ Overnight high-dose dexamethasone suppression test } \\
\hline Plasma cortisol level at $0800 \mathrm{~h}$ & & & & 18.3 & \\
\hline \multicolumn{6}{|c|}{ Two-day high-dose dexamethasone suppression test } \\
\hline Plasma cortisol level at $0800 \mathrm{~h}$ & 33.7 & 20.0 & 22.9 & & \\
\hline 24-h urinary free cortisol level & 1470 & 676 & 1489 & & \\
\hline
\end{tabular}

Table 1: Endocrinological studies (before adrenalectomy) in the five patients with primary pigmented nodular adrenocortical disease. ${ }^{\star}$ Overnight low-dose dexamethasone suppression test: $1 \mathrm{mg}$ dexamethasone orally at $2300 \mathrm{~h}$ and blood sampling for cortisol level the following morning at $0800 \mathrm{~h} .{ }^{* *}$ Two-day low-dose dexamethasone suppression test: $0.5 \mathrm{mg}$ dexamethasone orally every $6 \mathrm{~h}$ for 2 days and blood sampling for cortisol level at $0800 \mathrm{~h}$ on the third day of testing. Collecting 24-h urine for free cortisol level from $0800 \mathrm{~h}$ on the second day to $0800 \mathrm{~h}$ on the third day after dexamethasone administration. \$Overnight high-dose dexamethasone suppression test: $8 \mathrm{mg}$ dexamethasone orally at $2300 \mathrm{~h}$ and blood sampling for cortisol level the following morning at $0800 \mathrm{~h}$. $\$ \$$ Two-day high-dose dexamethasone suppression test: $2 \mathrm{mg}$ dexamethasone orally every $6 \mathrm{~h}$ for 2 days and blood sampling for cortisol level at $0800 \mathrm{~h}$ on the third day of testing. Collecting 24-h urine for free cortisol level from $0800 \mathrm{~h}$ on the second day to $0800 \mathrm{~h}$ on the third day after dexamethasone administration.

\section{Case II-4}

The detailed history of this patient was reported by Tung et al., 2009 [9].Briefly, in October 2001, a 45-year-old man (the younger brother of the index patient; born in June 1956) (Figure 1) presented to our clinic with a cushingoid appearance. His height was $157 \mathrm{~cm}$; weight, 64 $\mathrm{kg}$; and blood pressure, 146/94 mm Hg. The results of endocrine studies revealed adrenal CS (Table 1). An adrenal scintigraphy using NP-59 showed uptake of the tracer in the left adrenal on the second day and in the right adrenal gland on the fourth day after NP-59 injection [9]. CT of the abdomen revealed a nodule ( $2 \mathrm{~cm}$ diameter) on the left adrenal and a normal-appearing right adrenal gland [9]. A laparoscopic left adrenalectomy was performed in November 2001. The cut surface of the excised left adrenal nodule showed multiple 
Citation: $\quad$ Tung SC, Hwang DY, Yang JW, Ng HY, Lee CT (2014) Heterogeneous Clinical Manifestations of Cushing's Syndrome in a Family with Primary Pigmented Nodular Adrenocortical Disease. J Steroids Horm Sci 5: 144. doi:10.4172/2157-7536.1000144

Page 4 of 6

small black nodules. Diffuse PPNAD was confirmed microscopically [9].

In December 2001, baseline plasma cortisol levels still demonstrated a loss of normal circadian rhythm. An overnight LDDST failed to suppress plasma cortisol $(14.0 \mu \mathrm{g} / \mathrm{dL})$. In January 2002 , a repeated CT of the abdomen revealed a residual nodule $(1.5 \mathrm{~cm}$ diameter $)$ on the left adrenal gland. Thus, a left total adrenalectomy

Sixty-nine months after the second procedure, cushingoid appearance of the patient was still absent, although his overnight LDDST revealed a non-suppressible plasma cortisol concentration $(12.7 \mu \mathrm{g} / \mathrm{dL})$. The patient reports via a telephone conversation that the remission of cushingoid features continues 12 years after the second procedure. Analysis of genomic DNA obtained from peripheral blood leukocytes and the paraffin-embedded left adrenal tissues both identified a c.46C > T mutation (p.R16X) in the PRKAR1A gene.

\section{Case III-7}

A 25 -year-old man (the third son of case II-4; born in July 1981) (Figure 1) came to our outpatient department in August 2006 due to a moon-faced appearance for 1year and weight gain of 5-6 $\mathrm{kg}$ in the preceding 1.5 years. As noted above, his father had PPNAD. His height was $157 \mathrm{~cm}$; weight, $58 \mathrm{~kg}$; and blood pressure, 128/72 $\mathrm{mm} \mathrm{Hg}$. Physical examination revealed moon face with an excess of acne, buffalo hump, and abdominal obesity. An absence of normal circadian plasma cortisol fluctuations was observed (baseline plasma cortisol levels of $17.3 \mu \mathrm{g} / \mathrm{dL}$ at $0800 \mathrm{~h}$ and $14.1 \mu \mathrm{g} / \mathrm{dL}$ at $1600 \mathrm{~h}$ ) (Table 1). Baseline plasma ACTH level was $14.6 \mathrm{pg} / \mathrm{mL}$. In September 2006, an adrenal scintigraphy using NP-59 showed bilateral adrenal uptake of the tracer on the fifth day after NP-59 injection. Abdominal CT did not find any adrenal nodule in September 2006, August 2007, or April 2010. Left total adrenalectomy via a left flank approach was performed in June 2010. Diffuse PPNAD was proved microscopically. The patient refused right adrenalectomy despite persistent manifestations of CS after left total adrenalectomy. Analysis of this patient's genomic DNA from peripheral blood leukocytes identified a c.46C $>\mathrm{T}$ mutation (p.R16X) in the PRKAR1A gene.

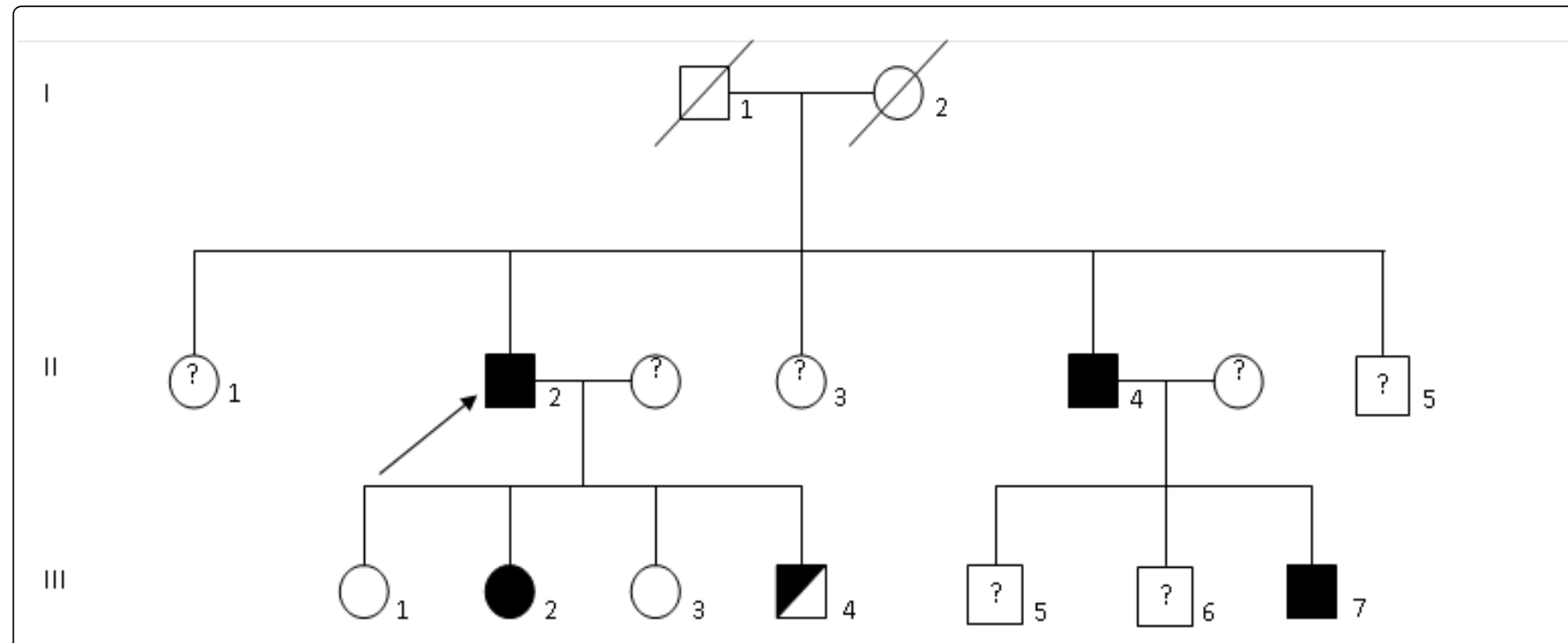

Figure 1: Pedigree of the family. The arrow identifies the index patient (II-2). Squares denote male family members, circles female family members, and a diagonal line a deceased member. Primary pigmented nodular adrenocortical disease with mutation of regulatory subunit R1A of protein kinase A gene and overt Cushing's syndrome. Carrier of gene mutation of regulatory subunit R1A of protein kinase A gene in latent stage of Cushing's syndrome. Unknown for Cushing's syndrome or gene mutation. ? No Cushing's syndrome and no gene mutation

\section{Discussion}

Since the first description in 1985 of "the complex of myxomas, spotty pigmentation, and endocrine overactivity" [10], now known as "Carney complex", more than $500 \mathrm{CNC}$ patients have been reported from all ethnicities, and the majority of them (almost 70\%) presented with a positive family history $[11,12]$. CNC is an autosomal dominant disorder featuring skin lesions, cardiac and other myxomas, and different types of endocrine tumors including PPNAD, growth hormone-secreting pituitary tumors, gonadal and thyroid neoplasms, and rarely, benign and malignant psammomatous melanotic schwannomas [13]. The most frequent endocrine manifestation of CNC is PPNAD [14]. There seems to be a bimodal age distribution of PPNAD among CNC patients, a minority present during the first 2-3 years, whereas the majority manifest in the second and third decade of life [2]. Our patients in case II-2, II-4, III-2, and III-7, with PPNAD and mutation of the PRKAR1A gene, meet the diagnostic criteria of $\mathrm{CNC}$ set by Stratakis et al. [2]. The case III- 4 patient has a biological father afflicted with CNC and is a case of PPNAD in the latent phase of CS with mutation of the PRKAR1A gene. Therefore, the case III-4 patient is also classified as having CNC. 
Page 5 of 6

The clinical manifestations of CS in patients with PPNAD can be divided into three stages: (a) overt (CS present clinically and biochemically), (b) subclinical (no clinical features of CS, but detectable adrenocortical hyperfunction or autonomy or both), or (c) latent (no clinical or laboratory evidence of CS, but the genetic trait is present) [9]. Our index patient (case II-2) still presented overt CS after unilateral total adrenalectomy (Table 2). In case III-2, the patient progressed through all three stages of CS (latent, subclinical, and overt) after unilateral (left) total adrenalectomy, and this progression from latent to overt CS occurred over a period of $>11$ years in the right PPNAD [8]. For case III-4, the patient remains in the latent CS stage despite carrying the PRKAR1A gene mutation common to his afflicted family members. In case II-4, the first two stages of CS (latent and subclinical) are observed and the remission period of CS persists for $>12$ years after unilateral total adrenalectomy (Table 2). In case III-7, overt CS persists after unilateral total adrenalectomy (Table 2). Thus, all the five family members with PPNAD displayed various clinical manifestations of CS even though they each had the same mutation (c. $46 \mathrm{C}>\mathrm{T}$ ) in the PRKAR1A gene.

Establishing the diagnosis of PPNAD can be challenging, particularly when PPNAD is the only manifestation of the disease and there are no other afflicted family members. In addition, patients with the disease not only may present atypical forms of CS, such as cyclical or episodic CS, but they may also have normal radiologic imaging or show only subtle nodularity $[15,16]$. Beyond 18 years of age, a unilateral $2-3 \mathrm{~cm}$ diameter adrenal macronodule is common in
PPNAD (as in our case II-2, II-4, and III-2) [5,17]. This can make it difficult to distinguish CS due to PPNAD from ACTH-independent unilateral adrenocortical adenoma based on radiological criteria only [9]. A paradoxical increase in 24-h UFC during the Liddle test can be used to identify PPNAD and distinguish it from other causes of adrenal CS $[18,19]$.

The hypercortisolism due to PPNAD resolves after bilateral adrenalectomy [5,15]; however, lifelong glucocorticoid replacement is required after this form of surgery. Mortality and morbidity because of adrenal insufficiency after bilateral total adrenalectomy were reported in patients with PPNAD [20-22]. Carney and Young reported that 6 out of 17 PPNAD patients that underwent unilateral adrenalectomy exhibited remission of their clinical features of CS [15]. Seven other patients had persistence of CS, two died postoperatively, and two were lost to follow-up. These authors also speculate that less than total adrenalectomy may have a place in some selected PPNAD patients who are asymptomatic or only minimally symptomatic [15]. We previously reported a case of PPNAD with remission of CS after unilateral adrenalectomy in 2009 (case II-4) [9]. Here we present additional objective data. For example, from case III-2 and II-4 (Table 2 ), the observation of larger size (by abdominal CT) and increased function (by adrenal scintigraphy) of the affected left adrenal gland compared to the right may assist in the decision to perform unilateral adrenalectomy as a choice for PPNAD patients to avoid lifelong glucocorticoid replacement therapy. Such a management approach for patients with PPNAD represents a form of patient-centered care.

\begin{tabular}{|c|c|c|c|c|c|c|c|c|c|}
\hline $\begin{array}{l}\text { Case } \\
\text { No. }\end{array}$ & Sex & $\begin{array}{lr}\text { Age } & (y r) \\
\text { at } & \text { first } \\
\text { surgery }\end{array}$ & $\begin{array}{l}\text { Manifestations of } \\
\text { Cushing's } \\
\text { syndrome (CS) }\end{array}$ & $\begin{array}{l}\text { Computed } \\
\text { tomography } \\
\text { findings }\end{array}$ & $\begin{array}{l}\text { Adrenal } \\
\text { scintigraphy* }\end{array}$ & Adrenalectomy & $\begin{array}{l}\text { Pathological } \\
\text { findings of } \\
\text { adrenal glands }\end{array}$ & $\begin{array}{l}\text { Features of } \\
\text { Carney } \\
\text { complex }\end{array}$ & $\begin{array}{l}\text { Gene } \\
\text { mutation }\end{array}$ \\
\hline II-2 & Male & 42 & $\begin{array}{l}\text { Overt CS } \\
\text { No remission of CS } \\
\text { after right total } \\
\text { adrenalectomy }\end{array}$ & $\begin{array}{lr}\text { Right } & \text { tiny } \\
\text { adrenal } & \text { nodule, } \\
\text { left } & \text { adrenal } \\
\text { nodule }(2 \mathrm{~cm})\end{array}$ & $\begin{array}{l}\text { Bilateral adrenal } \\
\text { uptake }\end{array}$ & $\begin{array}{l}\text { Bilateral total } \\
\text { adrenalectomy }\end{array}$ & $\begin{array}{l}\text { Bilateral diffuse } \\
\text { PPNAD }\end{array}$ & $\begin{array}{l}\text { PPNAD, } \\
\text { bilateral } \\
\text { papillary } \\
\text { thyroid } \\
\text { carcinoma }\end{array}$ & $\begin{array}{l}\text { PRKAR1A? } \\
\text { (c.46 C>T) }\end{array}$ \\
\hline III-2 & Female & 24 & $\begin{array}{l}\text { Three stages of CS } ¥ \\
\text { on different dates } \\
\text { Remission of CS for } \\
>11 \text { years after left } \\
\text { total adrenalectomy }\end{array}$ & 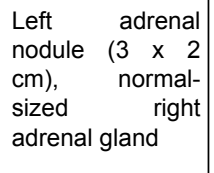 & $\begin{array}{ll}\text { Left } & \text { adrenal } \\
\text { uptake } & \\
& \end{array}$ & $\begin{array}{ll}\text { Left } & \text { total } \\
\text { adrenalectomy, } & \text { right } \\
\text { subtotal } & \\
\text { adrenalectomy } & \\
(80 \%) & \end{array}$ & $\begin{array}{lr}\text { Left } & \text { focal } \\
\text { PPNAD, } & \text { right } \\
\text { diffuse PPNAD }\end{array}$ & $\begin{array}{l}\text { PPNAD, } \\
\text { bilateral } \\
\text { thyroid cysts }\end{array}$ & $\begin{array}{l}\text { PRKAR1A? } \\
\text { (c.46 C>T) }\end{array}$ \\
\hline III-4 & Male & $32 \S$ & Latent CS & Not done & Not done & No & Unknown & No screened & $\begin{array}{l}\text { PRKAR1A? } \\
\text { (c.46 C>T) }\end{array}$ \\
\hline II-4 & Male & 45 & $\begin{array}{l}\text { Overt CS } \\
\text { Persistent remission } \\
\text { of } \\
\text { CS for }>12 \text { years } \\
\text { after left total } \\
\text { adrenalectomy }\end{array}$ & 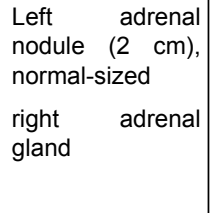 & $\begin{array}{l}\text { Earlier uptake of } \\
\text { left adrenal than } \\
\text { right }\end{array}$ & $\begin{array}{l}\text { Left total } \\
\text { adrenalectomy }\end{array}$ & $\begin{array}{l}\text { Left } \\
\text { PPNAD }\end{array}$ & $\begin{array}{l}\text { PPNAD, } \\
\text { bilateral } \\
\text { thyroid cysts }\end{array}$ & $\begin{array}{l}\text { PRKAR1A? } \\
\text { (c.46 C>T) }\end{array}$ \\
\hline III-7 & Male & 29 & $\begin{array}{l}\text { Overt CS } \\
\text { No remission of CS } \\
\text { after left total } \\
\text { adrenalectomy }\end{array}$ & $\begin{array}{l}\text { Normal-sized } \\
\text { bilateral adrenal } \\
\text { glands }\end{array}$ & $\begin{array}{l}\text { Bilateral adrenal } \\
\text { uptake }\end{array}$ & $\begin{array}{l}\text { Left total } \\
\text { adrenalectomy }\end{array}$ & $\begin{array}{ll}\text { Left } & \text { diffuse } \\
\text { PPNAD } & \end{array}$ & PPNAD & $\begin{array}{l}\text { PRKAR1A? } \\
\text { (c.46 C>T) }\end{array}$ \\
\hline
\end{tabular}

Table 2: Clinical characteristics in a family with primary pigmented nodular adrenocortical disease (PPNAD). *Adrenal scintigraphy: $131 \mathrm{I}-6$ iodomethyl-19-norcholesterol adrenal scintigraphy. ?PRKAR1A: regulatory subunit R1A of protein kinase A. ¥Three stages of CS: overt, subclinical, and latent Cushing's syndrome. 32: The patient was 32 years old when the gene study was performed in October 2011. 


\section{Conclusions}

The clinical manifestations of CS and imaging features in our intrafamilial PPNAD patients are heterogeneous. The three stages of CS (overt, subclinical, and latent) should be kept in mind in the management of PPNAD. Detailed adrenal imaging of PPNAD patients is necessary to assist with the decision to perform unilateral adrenalectomy.

\section{References}

1. Young WF, Carney JA, Musa BU, Wulffraat NM, Lens JW, et al. (1989) Familial Cushing's syndrome due to primary pigmented nodular adrenocortical disease: reinvestigation 50 years later. $\mathrm{N}$ Engl J Med 321:1659-1664.

2. Stratakis CA, Kirschner LS, Carney JA (2001) Clinical and molecular features of the Carney complex: diagnostic criteria and recommendations for patient evaluation. J Clin Endocrinol Metab 86: 4041-4046.

3. Stratakis CA, Carney JA, Lin JP, Papanicolaou DA, Karl M, et al. (1996) Carney complex, a familial multiple neoplasia and lentiginosis syndrome. Analysis of 11 kindreds and linkage to the short arm of chromosome 2. J Clin Invest 97: 699-705.

4. Travis WD, Tsokos M, Doppman JL, Nieman L, Chrousos GP, et al. (1989) Primary pigmented nodular adrenocortical disease: a light and electron microscopic study of eight cases. Am J Surg Pathol 13: 921-930.

5. Sarlis NJ, Chrousos GP, Doppman JL, Carney JA, Stratakis CA (1996) Primary pigmented nodular adrenocortical disease: reevaluation of a patient with Carney complex 27 years after unilateral adrenalectomy. J Clin Endocrinol Metab 82: 1274-1278.

6. Kirschner LS, Sandrini F, Monbo J, Lin JP, Carney JA, et al. (2000) Genetic heterogeneity and spectrum of mutations of the PRKAR1A gene in patients with the carney complex. Hum Mol Genet 9: 3037-3046.

7. Tung SC, Wang PW, Huang TL, Yang JW, Chen WJ (2005) Carney complex with primary pigmented nodular adrenocortical disease and bilateral papillary thyroid carcinoma occurring 11 years apart: a case report. Endocrinologist 4: 243-247.

8. Tung SC, Hwang DY, Yang JW, Chen WJ, Lee CT (2012) An unusual presentation of Carney complex with diffuse primary pigmented nodular adrenocortical disease on one adrenal gland and a nonpigmented adrenocortical adenoma and focal primary pigmented nodular adrenocortical disease on the other. Endocr J 59: 823-830.

9. Tung SC, Wang PW, Lee WC (2009) Remission of Cushing's syndrome in a patient with primary pigmented nodular adrenocortical disease with unilateral adrenalectomy: a case study. Endocrinologist 19: 75-78.

10. Carney JA, Gordon H, Carpenter PC, Shenoy BV, Go VL (1985) The complex of myxomas, spotty pigmentation, and endocrine overactivity. (Baltimore) 64: 270-283.
11. Bertherat J, Horvath A, Groussin L, Grabar S, Boikos S, et al. (2009) Mutations in regulatory subunit type $1 \mathrm{~A}$ of cyclic adenosine 5monophosphate-dependent protein kinase (PRKAR1A): phenotype analysis in 353 patients and 80 different genotypes. J Clin Endocrinol Metab 94: 2085-2091.

12. Courcoutsakis NA, Tatsi C, Patronas NJ, Lee CC, Prassopoulos PK, et al. (2013) The complex of myxomas, spotty skin pigmentation and endocrine overactivity (Carney complex): imaging findings with clinical and pathological correlation. Insights Imaging 4: 119-133.

13. Horvath A, Bertherat J, Groussin L, Guillaud-Bataille M, Tsang K, et al. (2010) Mutations and polymorphisms in the gene encoding regulatory subunit type 1-alpha of protein kinase A (PRKAR1A): an update. Hum Mutat 31: 369-379.

14. Pereira AM, Hes FJ, Horvath A, Woortman S, Greene E, et al. (2010) Association of the M1V PRKAR1A mutation with primary pigmented nodular adrenocortical disease in two large families. J Clin Endocrinol Metab 95: 338-342.

15. Carney JA, Young WF (1992) Primary pigmented nodular adrenocortical disease and its associated conditions. Endocrinologist 2:6-21.

16. Groussin L, Horvath A, Jullian E, Boikos S, Rene-Corail F, et al. (2006) A PRKAR1A mutation associated with primary pigmented nodular adrenocortical disease in 12 kindreds. J Clin Endocrinol Metab 91: 1943-1949.

17. Doppman JL, Travis WD, Nieman L, Miller DL, Chrousos GP, et al. (1989) Cushing syndrome due to primary pigmented nodular adrenocortical disease: findings at CT and MR imaging. Radiology 172: 415-420.

18. Stratakis CA, Sarlis N, Kirschner LS, Carney JA, Doppman JL, et al. (1999) Paradoxical response to dexamethasone in the diagnosis of primary pigmented nodular adrenocortical disease. Ann Intern Med 131: 585-591.

19. Bourdeau I, Lacroix A, Schürch W, Caron P, Antakly T, et al. (2003) Primary pigmented nodular adrenocortical disease: paradoxical responses of cortisol secretion to dexamethasone occur in vitro and are associated with increased expression of the glucocorticoid receptor. J Clin Endocrinol Metab 88: 3931-3937.

20. Imai T, Funahashi H, Tanaka Y, Tobinaga J, Wada M, et al. (1996) Adrenalectomy for treatment of Cushing syndrome: results in 122 patients and long-term follow-up studies. World J Surg 20: 781-786.

21. Shenoy BV, Carpenter PC, Carney JA (1984) Bilateral primary pigmented nodular adrenocortical disease. Rare cause of the Cushing syndrome. Am J Surg Pathol 8: 335-344.

22. Grant CS, Carney JA, Carpenter PC, van Heerden JA (1986) Primary pigmented nodular adrenocortical disease: diagnosis and management. Surgery 100: 1178-1184. 